Journal of Social Sciences (COES\&RJ-JSS)

ISSN (E): 2305-9249 ISSN (P): 2305-9494

Publisher: Centre of Excellence for Scientific \& Research Journalism, COES\&RJ LLC

Online Publication Date: $1^{\text {st }}$ July 2017

Online Issue: Volume 6, Number 3, July 2017

https://doi.org/10.25255/jss.2017.6.3.558.583

\title{
Secondary School Teachers' Classroom Management Practices: Their Implications for the Academic Performance of Grade 10 Students
}

\author{
Al-Rashiff H. Mastul \\ Prof. Kaberl O. Hajilan, Ph.D \\ Graduate School \\ Mindanao State University Tawi-Tawi College of Technology and \\ Oceanography, Bongao, Tawi-Tawi, Philippines
}

\begin{abstract}
:
Effective teaching and learning process is directly or indirectly influence by organized classroom management. Proper classroom management paves the way for the teacher to engage more towards students learning. As observed many of our students in Simunul Municipality performed poorly in almost all subject areas. The researcher believed that classroom management is crucial in the teaching and learning process in the classroom. This study explores the teachers'perception on classroom management and its relation to select profile of the teachers and students academic performance.Descriptive survey design was used to determine the classroom management practices of 78 secondary school teachersin Simunul, Tawi tawi Philippines using Instructional and Behavioral Management Scale.Findings revealed that teachers' perceptions with regard to the concept of classroom management favored more on instructional management than behavioral management. The demographic variables did not significantly influence both behavioral and instructional management practices except for the monthly income which shows significant relationship to instructional management practices. Results also showed that Instructional and Behavioral Classroom Management Practices of teachers significantly affected with their monthly income, but not significantly related to the academic performance of Grade 10 students. From the results, it can be concluded that economic status of the teachers significantly influenced their classroom management practices. Thus, salary increase for the teachers, and other form of motivations or incentives are highly recommended.
\end{abstract}

Keywords:

Secondary School Teachers, Academic Performance, Classroom Management Practices

\section{Citation:}

Mastul, Al-Rashiff H. ; Hajilan, Prof. Kaberl O. Hajilan ; (2017); Secondary School Teachers' Classroom Management Practices: Their Implications for the Academic Performance of Grade 10 Students; Journal of Social Sciences (COES\&RJ-JSS), Vol.6, No.3, pp:558-583 ; DOI: 10.25255/jss.2017.6.3.558.583. 


\section{Background of the Study}

Teachers have an influencing role in the life of every student. They are like bacons of light, guiding the students in the formative years of their lives. Teachers remain with them throughout their lives. Teaching and learning may take place through effective classroom management. Classroom management means setting the rules and procedure to maintain order so that learning may result. A good management begins with a clear understanding of rules, preferably, rules that are worked positively. In fact, Wang, Haertel, \& Walberg (1994) as cited by Martin and Sass (2010) believed that classroom management greatly influence classroom climate and at the same time promote students engagement in classroom activities and quality of learning.

Yavuz (2009) also said that when teachers adopted the role of creating and maintaining an effective learning environment through organized classroom management teachinglearning process will become more successful compared to the teachers who want to have power and emphasize discipline in the class. Bradley, Pauley, and Parley (2005), added that students affective and cognitive development will be improved when positive studentteacher relationship and increase motivation in the classroom is practice. Good classroom managers will create a friendly learning environment and do not use verbal reprimand, threaten, embarrass, suspend or expel students (Geiger, 2000).

Shawer(2006) believed that classroom management involves four strategies namely:organizing, teaching management, teacher-students relationship and teacher punishment/reward. These strategies include administrative rules and actual classroom pedagogical activities. Shawer, Gilmore, and Banks, (2009), pointed out that when students tasks beyond are beyond their reach, the result is student objection or dissatisfaction, whereas, easy tasks leave no option to students but talking to pass the time. It is believed that believed that children's' behavior greatly influence in the school and shaped through social context in the environment during their development stage (Kauffman, 2005). Classroom environment plays a vital roleof learner's behavioral development (Kauffman, 2005; Greer-Chase, Rhades, and Kellam, 2002). A maladapted behavior is believed to be influences by classroom management practices of teachers in the early grades. Research has indicated that aggressive students in aggressive or disruptive environments are more likely to be aggressive in later grades and classroom management are necessary to improve both academic and behavioral outcomes for students (Greer-Chase et al, 2002).

Classroom management varies from teacher to teacher; due to individual differences they have also different beliefs and attitudes in analyzing and understanding their student behavior (Maartin and Saas, 2010 citing Erden and Wolfgang, 2004 and Smart, 2009). Teacher's perceptions about classroom management and philosophy in life affects on how classroom should be managed. Maintaining classroom management and order depend on the teachers' ability to utilize fully the involvement of students by stimulating, directing, and guiding their classroom activities. Research study of Victor (2005) on the impact of classroom management techniques on student's behaviorconcluded that students' behavior significantly improve when classroom is environmentally friendly such as decrease in compliance, shouting and tantrum. Schmidt (2006) research study also concluded that teachers' classroom management training is necessary for the teachers to respond the different characteristics, behavior and instructional needs of the students in addition to developing appropriate relationship with students and parents. A well-managed classroom 
fosters meaningful learning and preventsthe development of academic and emotional problems among students (Bloom, 2009; Marinez, 2009). Aiken (1990) as cited by Cagampan-Clors (2011) suggested that $90 \%$ of the total reinforcement to influence students' academic performance and classroom behavior lies on the teachers' classroom management skills because teachers are the manager, motivators, providers and buildersevery student.

\section{Conceptual Frame Work}

The conceptual framework presents the independent variables focus on teachers' classroom management practices which are limited to behavioral and instructional management only.The demographic profile of the respondents such as gender, age, and educational attainment, length of service, monthly income and number of children were considered to be intervening variables and assumed to have significant relationship to the independent variables and dependent variable which is the academic performance of the grade 10 students.

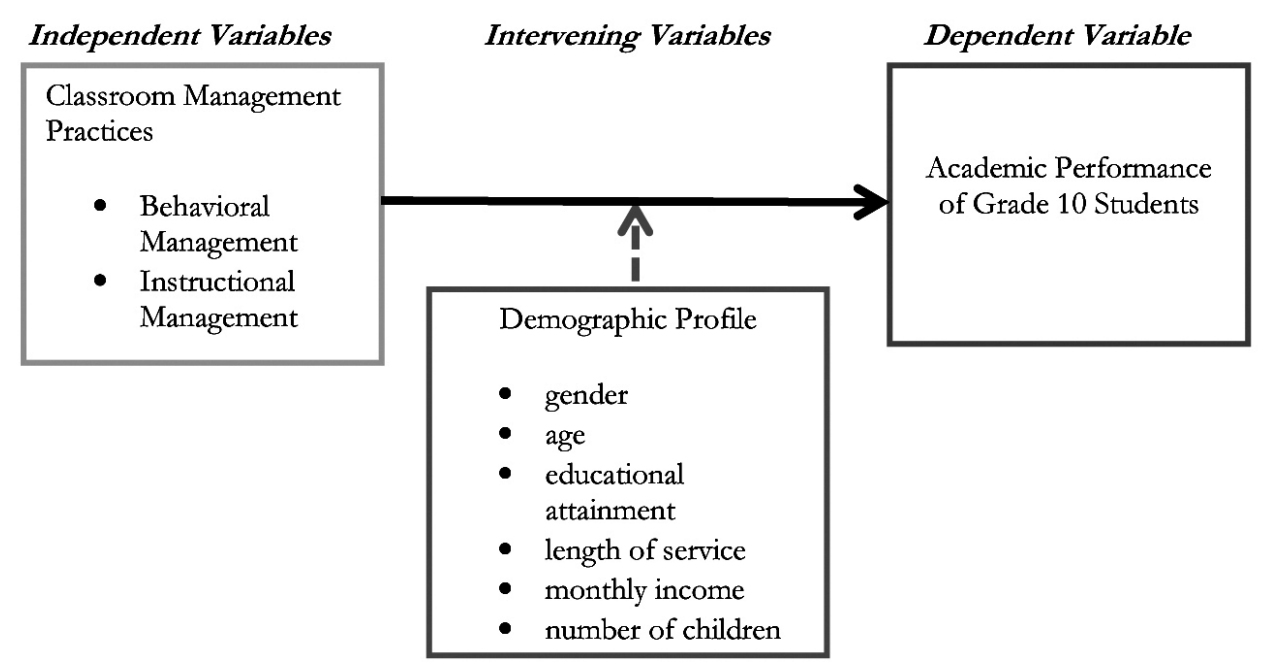

Fig. 1.Schematic Diagram of the Variables Investigated in the Study

\section{Literature Review}

Classroom management has been defined broadly as any action a teacher takes to create an environment that supports and facilitates both academic and social-emotional learning (Evertson and Emmer, 2006). Martin and Sass (2009) mentioned that it is important that the teachers should recognized behavior and instructional management style.Classroom management is so important to effective teaching and to control disruptive behavior in order to allocate as much as possible of classroom time and effort to teaching and learning activities (Shawer, 2010: 23; citing Victor, 2005). Effective classroom management guides the way to stable teaching and learning in the class. The most common request of assistance from teachers is related to behavior and classroom management (Rose and Ballup, 2005). Ingersoll and Smith (2003) mentioned that school discipline issues such disruptive behavior and violence is prominent among new teachers when classroom organization and behavior management is poorly implemented. More often, new teachers 
typically express concerns about effective means to handle disruptive behavior (Brown and Tomic, 2000).

Manzano (2003) pointed out that the most effective classroom managers (teachers) have the following characteristics: they show appropriate levels of providing clear purpose and strong guidance regarding both academics and student behavior; exhibit appropriate levels ofcooperation where the students and teacher function as a team; and are aware of high needs of students and have specific strategies and techniques for meeting some of their needs. Campbell and Yavuz (1999) also believed that teachers who have adopted the role of creating and maintaining an effective learning environment in the classroom become more successful compared to the teachers who have power and emphasize discipline in the classroom. Packaged interventions using antecedent strategies (e.g., posting of rules, teacher movement, precession request), reinforcement strategies (e.g., token economy, mystery behavior), and punishment strategies to respond to inappropriate behavior (e.g., response cost) have been used effectively to reduce disruptive behavior ( $\mathrm{Di}$ - MartiniScully et.al. 2000).

Jovelete and Nelson (2010), emphasize that classroom should positively promote behavioral expectations for the students. Sayeski and Brown(2011) recommended that teachers should practice stimulating instruction providing students with high levels of engagement. In order to limit problem behaviors in the classroom; teachers should be actively supervising by moving around the classroom so that they are aware of things going on in the room (Depry and Sugain, 2002). Physical proximity and nonverbal prompts (e.g., prompting to the text) while the teacher is moving around the room will also help limit the problem behaviors and keep students engaged in the classroom activities (Depray and Sugain, 2002). M.C.Intoch et.al. (2004) said that interacting with students to teach behavior, pre-correct, and build positive relationships will also prevent inappropriate behavior in the classroom. Martin and Saas (2010) in Buddahim (2012) in their study on an integration of theoretical perspective found out that the underlying continuum of control lies with the Behavioral Instructional Management Scale (BIMS) and they hypothesized three approaches to teacher-student interaction namely: noninterventionist, interventionist, and interactionalist.

Woolfolk, Hoy and Weinstein (2006) commented that it makes sense that the teacher's approach to instruction would be related to their methods of behavior management. Martin and Saas (2010) made mention that educators have created an oxymoron. While there is little research to dispute this opposing argument, Garett's (2006) qualitative study lends some evidences that a lack of connection between how teachers thought about instruction as teacher-student centered they did not view behavior with the same idea.

Martin and Saas (2010:9), research findings revealed statistically the significant inverse relationships between instructional management and the component of teacher efficacy. Teachers with higher level of efficacy regarding instructional strategies, student engagement, and classroom management are less likely to take a direction in implementing tactics to manage instruction. Conversely, the relationship between behavioral management and the three teacher efficacy variables was relatively small, in short, this finding showed that how a teacher manages student behavior is likely unrelated to their perceived ability to effectively manage classroom instruction and keep students engaged. 
A case study conducted by Yousef (2012) among secondary teachers in Australia reported that teachers prefers to use the term classroom management by taking into consideration thorough preparation, delivery of materials, employing a discipline plan that involves proactive and reactive strategies and catering for her students' needs. Another case study presented by Jay Kay (2006), revealed that there are other understandingswhich influenceclassroom management discussions and practices with conception that what constitutes a comprehensive classroom management plan does not play a crucial part in her classroom practices.

The prevailing classroom management practices of the public school teachers in Bongao, Tawi-Tawi tend towards Instructional Management and Behavioral Management. She pointed out in her study that demographic variables of respondents such as age, gender, educational attainment and length of service are significantly related to teachers' classroom management practices particularly the Instructional Management and Behavioral Management. His findings also pointed that there is a significant inverse relationship between instructional management and the component of teacher efficacy. Teachers with higher efficacy regarding instructional strategies, student engagement, and classroom management are less likely to take a directive in implementing tactics to manage instruction. Conversely, the relationship between Behavioral Management and the three teacher efficacy variables were relatively small. In short, this finding showed that how a teacher manages student behavior is likely unrelated to their perceived ability to effectively manage classroom instruction and keep students engaged (Buddahim, 2012pp. 30 - 42). However, Hentson (2003) and Savran and Cakiruglu (2003) had mentioned that teacher efficacy is not necessarily strongly related to how a teacher handles classroom management.

\section{Methodology}

\section{Research Locale and Participants}

The study was conducted in eight secondary schools in Simunul, Tawi-Tawi Philippines. These secondary schools are of two categories: The national high schools and MSUTCTO secondary schools. These secondary schools are located in different areas or districts of Simunul. A total of eight secondary schools were taken asrespondentschools. These are: MSU-TCTO Bakong High School, HadjiOmarsaniTambut National High School, MSU-TCTO Tampakan High School and Ummat National High School are within the West Simunul District. The MSU-TCTO Tubig-Indangan High School and TubigIndangan National High School are located in Tubig-Indangan District. The remaining two, MSU-TCTO Manuk-Mangkaw High School and Manuk-Mangkaw National High School areinManuk-Mangkaw District.The study were participated by seventy eight (78) high school teachers from the select government owned Secondary Schools in the Island during school year 2015-2016.

\section{Research Design}

A quantitative descriptive survey research design was used to determine the classroom management practices of the secondary school teachers. It was also used to determine if there were significant differences in their practices by gender, age, and educational attainment, length of service, monthly income and number of children. 


\section{Research Instrument}

Research instruments used in the study was adapted from Martin and Saas (2010) study, the Behavioral and Instructional Management Scale (BIMS). The instruments for instructional and behavioral management were combined. Another research instrument was adapted from the research instrument used by Buddahim(2012) with some revisions was adopted in this study. The validity and reliability of the research questionnaire was already undertaken by the researcher prior to distribution of the research instruments. Thus, conducting the test for the purpose is not necessary.

\section{Procedure}

The researcher had made entry protocol in each research area. The data were gathered with the help of a coordinator hired by the researcher. Survey questionnaire were given randomly to each participants. The data were then checked immediately in the field while there was enough time to check the questionnaire collected, so that "no response" cases were minimized. Interview was also made randomly to the participants for triangulation of the collected data. After all the data has been collected, Statistical Package for Social Sciences (SPSS) was used to analyze the data quantitatively as presented in the questionnaire. Specific statistical treatments used were percentage distribution, correlation and mean. To measure differences among variables, Analysis of Variance (ANOVA) test was also used.

\section{Findings}

The questionnaire draws information from the respondents such as the demographic profile in the first part that includes age, gender, civil status, educational attainment, work experience, monthly income, and number of children, while the second part was focused on teachers' classroom management practices as measured by Instructional Management Scale (IMS) and Behavioral Management Scale (BMS). All of these variables were coded and summarized in the preceding presentations. Statistical tools from the IBM SPSS Statistics version 22 such as frequency distribution tables, mean, standard deviation, Pearson Correlation Coefficient $r$, and one-way analysis of variance (ANOVA) with post hoc tests were utilized and performed at the 0.05 level of significance.

Table 1Distribution of Teacher-Respondents Demographic Profile

\begin{tabular}{|c|c|c|c|}
\hline Demographic Profiles & & Frequency & Percent \\
\hline \multicolumn{4}{|l|}{ Gender Distribution } \\
\hline Not Indicated & & 1 & 1.3 \\
\hline Male & & 25 & 32.1 \\
\hline \multirow[t]{2}{*}{ Female } & & 52 & 66.7 \\
\hline & TOTAL & 78 & 100 \\
\hline \multicolumn{4}{|l|}{ Age Distribution } \\
\hline Not Indicated & & 1 & 1.3 \\
\hline $20-25$ years old & & 1 & 1.3 \\
\hline 26 - 30 years old & & 18 & 23.1 \\
\hline 31 - 35 years old & & 7 & 9.0 \\
\hline
\end{tabular}




\begin{tabular}{|c|c|c|c|}
\hline 36 - 40 years old & & 12 & 15.4 \\
\hline 41 - 45 years old & & 13 & 16.7 \\
\hline 46 and over & & 26 & 33.3 \\
\hline & TOTAL & 78 & 100 \\
\hline \multicolumn{4}{|c|}{ Highest Education Attainment } \\
\hline Not Indicated & & 2 & 2.6 \\
\hline BS/AB & & 19 & 24.4 \\
\hline BSE/AgEd & & 28 & 35.9 \\
\hline MA Units & & 29 & 37.2 \\
\hline & TOTAL & 78 & 100 \\
\hline \multicolumn{4}{|c|}{ Length of Service in Years } \\
\hline $1-5$ years & & 19 & 24.4 \\
\hline $6-10$ years & & 13 & 16.7 \\
\hline $11-15$ years & & 10 & 12.8 \\
\hline $16-20$ years & & 13 & 16.7 \\
\hline 21 and above & & 23 & 29.5 \\
\hline & TOTAL & 78 & 100 \\
\hline \multicolumn{4}{|c|}{ Monthly Income } \\
\hline Not Indicated & & 2 & 2.6 \\
\hline P5,000.00 - P10,000.00 & & 14 & 17.9 \\
\hline P11,000.00 - P16,000.00 & & 7 & 9.0 \\
\hline P17,000.00 - P22,000.00 & & 42 & 53.8 \\
\hline $\mathrm{P} 23,000.00$ - P28,000.00 & & 5 & 6.4 \\
\hline P29,000.00 and Above & & 8 & 10.3 \\
\hline & TOTAL & 78 & 100 \\
\hline \multicolumn{4}{|c|}{ Number of Children } \\
\hline Not Indicated & & 10 & 12.8 \\
\hline $0-3$ & & 33 & 42.3 \\
\hline $4-7$ & & 28 & 35.9 \\
\hline \multirow[t]{2}{*}{$8-11$} & & 7 & 9.0 \\
\hline & TOTAL & 78 & 100 \\
\hline
\end{tabular}

Table 1shows that of 78 teacher-respondents by gender, where majorities $(66.7 \%)$ are femalesand only $32.1 \%$ are male. The biggest number $(33.3 \%)$ or 26 of the teacherrespondents belong to the age bracket of 46 years old and above, assumed to the most experienced, followed by age bracket of $26-30$ years old with (23.1\%),13 of them or $16.7 \%$ belong to the age bracket of 41 to 45 years old, and so on. Majority (BS/AB = $24.4 \%, \mathrm{BSE} / \mathrm{AgEd}=35.9 \%$ ) of the teacher-respondents are not engaged in post graduate. Only few $(37.2 \%)$ earned MA units in their post graduate studies. The biggest number, 
$(29.5 \%)$ of the respondents were 21 years in service, followed by $24.4 \%$ whose service is between 1 and 5 years,and the rest with service between 6 and 20 years ranging from $12.8 \%$ to $16.7 \%$.More than half $(53.8 \%)$ of the teacher-respondents are with monthly income ranging from $\mathrm{P} 17,000.00$ to $\mathrm{P} 22,000.00$, about $17.9 \%$ or 14 of them are still in the lowest bracket of monthly income while only $10.3 \%$ whose monthly income ranged from P29,000.00 and more, the biggest number of the respondents, have 3 children, while $35.9 \%$ or 28 have 4 to 7 children and $9 \%$ or 7 are with 8 to 11 children while the rest did not indicate the number of children they have in the family.

\section{Teachers' Classroom Management Practices by School}

The teachers' classroom management practices were measured by behavioral and instructional management scales (BIMS). This research instrument was revised and validated by Martin and Saas (2010); it has 24 statements 12 of which measure behavioral management and the other 12 measure instructional management of the teachers in the classroom.

Table 2 Teachers' Classroom Management Practices as Measured by Instructional Management Scale (IMS) for MSU-TCTO Bakong High School

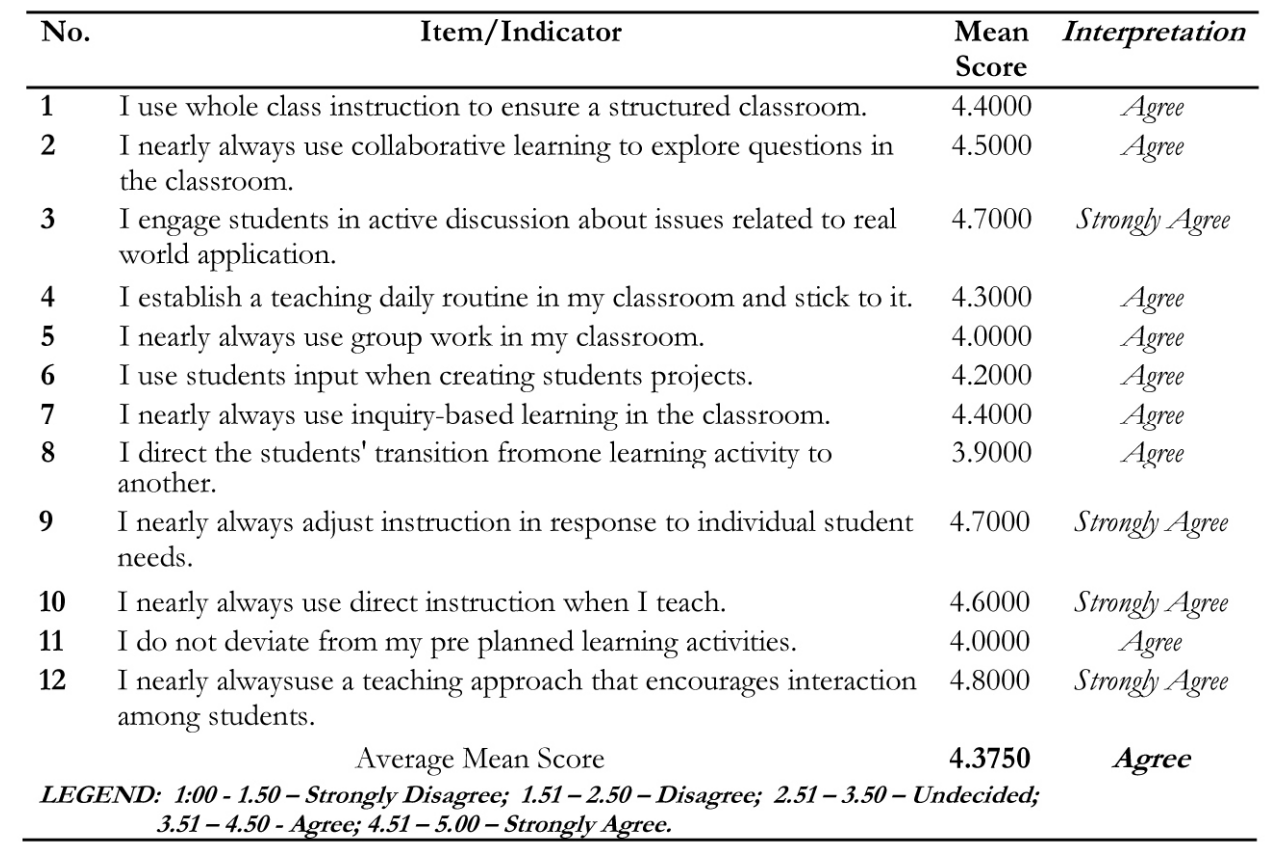

Table 2 shows the responses coming from MSU-TCTO Bakong High School teachers where the responses' mean score is $\mathbf{4 . 3 7 5 0}$ which means they "agree" in all the items in the Instructional Management Scales (IMS) and in fact in items 3, 9, 10 and 12 responses indicated a "strongly agree". Teachers displayed more of instructional management than behavioral management, which tends to emphasize more on the cognitive development of the learners. This is relevant to the idea of Yavuz (2009) citing Campbell R. J, Evan L; and Neil S. R (1991) pointed out the teachers who have adopted the roll of creating and 
maintaining learning environment in classroom become more successful compared to the teachers who want to have power and emphasize discipline in the classroom.

Table 3Teachers' Classroom Management Practices as Measured by Behavioral Management Scale (BMS) for MSU-TCTO Bakong High School

\begin{tabular}{|c|c|c|c|}
\hline No & Item/Indicator & $\begin{array}{l}\text { Mean } \\
\text { Score }\end{array}$ & Interpretation \\
\hline 1 & $\begin{array}{l}\text { I almost always intervene when student talk at in appropriate times during } \\
\text { class. }\end{array}$ & 2.7000 & Undecided \\
\hline 2 & I strongly limit student chatter in the classroom. & 2.8000 & Undecided \\
\hline 3 & I reward students for good behavior in the classroom & 4.6000 & Strongly Agree \\
\hline 4 & $\begin{array}{l}\text { If a student talks to a neighbor, I will move a student away from other } \\
\text { students. }\end{array}$ & 4.2000 & Agree \\
\hline 5 & I use inputs from students to create classroom rules. & 4.0000 & Agree \\
\hline 6 & I allow students to get out of their seats without permission. & 2.1000 & Disagree \\
\hline 7 & I ann strict when it connes to student compliance in nny classrovin. & 4.4000 & Agree \\
\hline 8 & I firmly redirect students back to the topic when they get off the tasks. & 3.8000 & Agree \\
\hline 9 & I insist that students in my classroom follow the rules at all times. & 4.6000 & Strongly Agree \\
\hline 10 & I closely monitor off-tasks behavior during class. & 3.9000 & Agree \\
\hline 11 & I strictly enforce classroom rules to control student behavior. & 4.4000 & Agree \\
\hline \multirow[t]{2}{*}{12} & $\begin{array}{l}\text { If student's behavior is defiant, I will demand that they comply with my } \\
\text { classroom rules. }\end{array}$ & 4.0000 & Agree \\
\hline & Average Mean Score & 3.7917 & Agree \\
\hline \multicolumn{4}{|c|}{$\begin{array}{l}\text { LEGEND: } 1.00 \text { - } 1.50 \text { - Strongly Disagree; } 1.51 \text { - } 2.50 \text { - Disagree; } 2.51 \text { - } 3.50 \text { - Undecided; } \\
3.51 \text { - } 4.50 \text { - Agree; } 4.51 \text { - } 5.00 \text { - Strongly Agree. }\end{array}$} \\
\hline
\end{tabular}

Table 3 are the responses coming from MSU-TCTO Bakong High School teachers mean score is 3.7917 which mean they "agree" in some of the items in the Behavioral Management Scales (BMS). It can be noted that the respondents are "undecided" regarding students talking/chatting inside the class, and in item 6 (I allow students to get out of their sits without permission.) indicated that they disagree, which means they do not tolerate students going outside the room during classes without proper permission. Items 3 and 9 got a higher mean which indicated a "strongly agree". High mean results indicating behavioral management approach of teacher showed that they have primary responsibility for control. Therefore, MSU-TCTO Bakong High School teachers less emphasize affective development in their style of managing the classroom.

Table 4Teachers' Classroom Management Practices as Measured by Instructional Management Scale (IMS) for MSU-TCTO Manuk-Mangkaw High School 


\begin{tabular}{|c|c|c|c|}
\hline No. & Item/Indicator & $\begin{array}{l}\text { Mean } \\
\text { Score }\end{array}$ & Interpretation \\
\hline $\mathbf{1}$ & I use whole class instruction to ensure a structured classroom. & 4.6667 & Strongly Agree \\
\hline 2 & $\begin{array}{l}\text { I nearly always use collaborative learning to explore questions in the } \\
\text { classroom. }\end{array}$ & 4.8333 & Strongly Agree \\
\hline 3 & $\begin{array}{l}\text { I engage students in active discussion about issues related to real world } \\
\text { application. }\end{array}$ & 4.6667 & Strongly Agree \\
\hline 4 & I establish a teaching daily routine in my classroom and stick to it. & 4.0000 & Agree \\
\hline 5 & I nearly always use group work in my classroom. & 4.5000 & Agree \\
\hline 6 & I use students input when creating students projects. & 4.6667 & Stronghy Agree \\
\hline 7 & I nearly always use inquiry-based learning in the classroom. & 4.6667 & Stronghy Agree \\
\hline 8 & I direct the students' transition fromone learning activity to another. & 3.8333 & Agree \\
\hline 9 & $\begin{array}{l}\text { I nearly always adjust instruction in response to individual student } \\
\text { needs. }\end{array}$ & 4.8333 & Strongly Agree \\
\hline 10 & I nearly always use direct instruction when I teach. & 4.0000 & Agree \\
\hline 11 & I do not deviate from my pre planned learning activities. & 4.1667 & Agree \\
\hline 12 & $\begin{array}{l}\text { I nearly alwaysuse a teaching approach that encourages interaction } \\
\text { among students. }\end{array}$ & 5.0000 & Strongly Agree \\
\hline & $\begin{array}{l}\text { Average Mean Score } \\
\text { END: } 1.00-1.50-\text { Strongly Disagree; } 1.51-2.50 \text { - Disagree; } 2.51 \\
4.50-\text { Agree; } 4.51-5.00-\text { Strongly Agree. }\end{array}$ & $\begin{array}{c}4.4861 \\
0-\operatorname{Und}\end{array}$ & Agree \\
\hline
\end{tabular}

Table 4 shows the responses coming from MSU-TCTO Manuk-Mangkaw High School teachers where the responses' mean score is $\mathbf{4 . 4 8 6}$ which means they "agree" in all the items in the Instructional Management Scales (IMS) and in fact in items 1, 2, 3, 6, 7, 9, and 12 responses indicated a "strongly agree". High mean results of most statements on instructional management indicated that the teachers observe more instructional management than behavioral management. The teachers keep on monitoring seat works of the students, structuring daily routines, use of lectures and students practice versus interactive and other participatory approaches to the instruction as their methodologist in order to encourage students to actively interact in the class.

Table 5Teachers' Classroom Management Practices as Measured by Behavioral School Management Scale (BMS) for MSU-TCTO Manuk-Mangkaw High

\begin{tabular}{|c|c|c|c|}
\hline No & Item/Indicator & $\begin{array}{l}\text { Mean } \\
\text { Score }\end{array}$ & Interpretation \\
\hline 1 & $\begin{array}{l}\text { I almost always intervene when student talk at in appropriate times during } \\
\text { class. }\end{array}$ & 4.5000 & Agree \\
\hline 2 & I strongly limit student chatter in the classroom. & 4.0000 & Agree \\
\hline 3 & I reward students for good behavior in the classroom & 5.0000 & Strongly Agree \\
\hline 4 & $\begin{array}{l}\text { If a student talks to a neighbor, I will move a student away from other } \\
\text { students. }\end{array}$ & 4.1667 & Agree \\
\hline 5 & I use inputs from students to create classroom rules. & 4.3333 & Agree \\
\hline 6 & I allow students to get out of their seats without permission. & 2.5000 & Disagree \\
\hline 7 & I am strict when it comes to student compliance in my classroom. & 4.0000 & Agree \\
\hline 8 & I firmly redirect students back to the topic when they get off the tasks. & 4.5000 & Agree \\
\hline 9 & I insist that students in my classroom follow the rules at all times. & 4.1667 & Agree \\
\hline 10 & I closely monitor off-tasks behavior during class. & 4.6667 & Strongly Agree \\
\hline 11 & I strictly enforce classroom rules to control student behavior. & 5.0000 & Strongly Agree \\
\hline 12 & $\begin{array}{l}\text { If student's behavior is defiant, I will demand that they comply with my } \\
\text { classroom rules. }\end{array}$ & 4.1667 & Agree \\
\hline \multicolumn{2}{|r|}{ Average Mean Score } & 4.2500 & Agree \\
\hline \multicolumn{4}{|c|}{$\begin{aligned} \text { LEGEND: } & 1.00-1.50 \text { - Strongly Disagtee; } 1.51-2.50 \text {-Disagree; } 2.51-3.50 \text {-Undecided; } \\
& 3.51-4.50-\text { Agree; } 4.51-5.00-\text { Strongly Agree. }\end{aligned}$} \\
\hline
\end{tabular}

Table 5 shows the responses coming from MSU-TCTO Manuk-Mangkaw High School teachers where the responses' mean score is $\mathbf{4 . 2 5 0 0}$ which means they "agree" to almost 
all of the items in the Behavioral Management Scales (BMS) except that of in item 6 (I allow students to get out of their seats without permission.) indicated that they "disagree" which means going outside the classroom during classes without proper permission is not allowed. While items 3, 10 and 11 indicated a "Strongly Agree" which means, that the teachers of this school believe that teachers with more power to emphasize discipline are more successful than the teachers who only create and maintain learning environment in the classroom.

Table 6Teachers' Classroom Management Practices as Measured by Instructional Management Scale (IMS) for MSU-TCTO Tubig-Indangan High School

\begin{tabular}{|c|c|c|c|}
\hline No & Item/Indicator & $\begin{array}{l}\text { Mean } \\
\text { Score }\end{array}$ & Interpretation \\
\hline 1 & I use whole class instruction to ensure a structured classroom. & 4.6667 & Strongly Agree \\
\hline 2 & $\begin{array}{l}\text { I nearly always use collaborative learning to explore questions in the } \\
\text { classroom. }\end{array}$ & 4.3333 & Agree \\
\hline 3 & $\begin{array}{l}\text { I engage students in active discussion about issues related to real world } \\
\text { application. }\end{array}$ & 4.8333 & Strongly Agree \\
\hline 4 & I establish a teaching daily routine in my classroom and stick to it. & 4.5000 & Agree \\
\hline 5 & I nearly always use group work in my classroom. & 4.1667 & Agree \\
\hline 6 & I use students input when creating students projects. & 4.3333 & Agree \\
\hline 7 & I nearly always use inquiry-based learning in the classroom. & 4.3333 & Agree \\
\hline 8 & I direct the students' transition fromone learning activity to another. & 4.5000 & Agree \\
\hline 9 & I nearly always adjust instruction in response to individual student needs. & 4.6667 & Strongly Agree \\
\hline 10 & I nearly always use direct instruction when I teach. & 4.6667 & Strongly Agree \\
\hline 11 & I do not deviate from my pre planned learning activities. & 4.5000 & Agree \\
\hline \multirow[t]{2}{*}{12} & $\begin{array}{l}\text { I nearly alwaysuse a teaching approach that encourages interaction among } \\
\text { students. }\end{array}$ & 4.6667 & Strongly Agree \\
\hline & Average Mean Score & 4.5139 & Strongly Agree \\
\hline \multicolumn{4}{|c|}{$\begin{array}{l}\text { LEGEND: } 1.00 \text { - } 1.50 \text { - Strongly Disagree; } 1.51 \text { - } 2.50 \text { - Disagtee; } 2.51 \text { - } 3.50 \text { - Undecided; } \\
3.51 \text { - 4.50 - Agree; } 4.51 \text { - } 5.00 \text { - Strongly Agtee. }\end{array}$} \\
\hline
\end{tabular}

Table 6shows the responses coming from MSU-TCTO Tubig-Indangan High School teachers where the responses' mean score for the Instructional Management Scales (IMS) is $\mathbf{4 . 5 1 3 9}$ which mean "strongly agree" to items $1,3,9,10$, and 12, and simply "agree" to the rest of the items. To items 1, 3, 9, 10 and 12 they answered "Strongly Agree". This means that the teachers work to find solutions acceptable to both teacher-student and use some of the same techniques as the previous schools mentioned. This school got the highest average mean score on instructional management than the rest of the secondary schools in Simunul.

Table 7 Teachers' Classroom Management Practices as Measured by Behavioral School Management Scale (BMS) for MSU-TCTO Tubig-Indangan High 
Journal of Social Sciences (COES\&RJ-JSS), 6(3), pp. 558-583

\begin{tabular}{|c|c|c|c|}
\hline No. & Item/Indicator & $\begin{array}{l}\text { Mean } \\
\text { Score }\end{array}$ & $\begin{array}{c}\text { Interpretatio } \\
n\end{array}$ \\
\hline 1 & I almost always intervene when student talk at in appropriate times during class. & 4.0000 & Agree \\
\hline 2 & I strongly limit student chatter in the classroom. & 4.3333 & Agree \\
\hline 3 & I reward students for good behavior in the classroom & 4.6667 & Strongly Agree \\
\hline 4 & If a student talks to a neighbor, I will move a student away from other students. & 4.3333 & Agree \\
\hline 5 & I use inputs from students to create classroom rules. & 4.1667 & Agree \\
\hline 6 & I allow students to get out of their seats without permission. & 1.0000 & $\begin{array}{l}\text { Strongly } \\
\text { Disagree }\end{array}$ \\
\hline 7 & I am strict when it comes to student compliance in my classroom. & 5.0000 & Strongly Agree \\
\hline 8 & I firmly redirect students back to the topic when they get off the tasks. & 4.5000 & Agree \\
\hline 9 & I insist that students in my classroom follow the rules at all times. & 4.6667 & Strongly Agree \\
\hline 10 & I closely monitor off-tasks behavior during class. & 4.6667 & Strongly Agree \\
\hline 11 & I strictly enforce classroom rules to control student behavior. & 5.0000 & Strongly Agree \\
\hline 12 & $\begin{array}{l}\text { If student's behavior is defiant, I will demand that they comply with my } \\
\text { classroom rules. }\end{array}$ & 4.5000 & Agree \\
\hline & Average Mean Score & 4.2361 & Agree \\
\hline
\end{tabular}

Table 7 shows the responses coming from MSU-TCTO Tubig-Indangan High School teachers where the responses' mean score is $\mathbf{4 . 2 3 6 1}$ which means they "agree" to almost all of the items in the Behavioral Management Scales (BMS) except that item 6 (I allow students to get out of their seats without permission.) which indicated that they "strongly disagree" as the previous schools did also. They answered "Strongly Agree" to items 3, 6, 9, 10 and 11 which indicated the school did the same behavioral management in the classroom as what the other secondary schools.

Table 8Teachers' Classroom Management Practices as Measured by Instructional Management Scale (IMS) for MSU-TCTO Tampakan High School

\begin{tabular}{|c|c|c|c|}
\hline No. & Item/Indicator & $\begin{array}{l}\text { Mean } \\
\text { Score }\end{array}$ & Interpretation \\
\hline 1 & I use whole class instruction to ensure a structured classroom. & 4.3333 & Agree \\
\hline 2 & I nearly always use collaborative learning to explore questions in the classroom. & 4.3333 & Agree \\
\hline 3 & $\begin{array}{l}\text { I engage students in active discussion about issues related to real world } \\
\text { application. }\end{array}$ & 4.5000 & Agree \\
\hline 4 & I establish a teaching daily routine in my classroom and stick to it. & 4.0000 & Agree \\
\hline 5 & I nearly always use group work in my classroom. & 4.5000 & Agree \\
\hline 6 & I use students input when creating students projects. & 3.8333 & Agree \\
\hline 7 & I nearly always use inquiry-based learning in the classroom. & 4.1667 & Agree \\
\hline 8 & I direct the students' transition fromone learning activity to another. & 4.0000 & Agree \\
\hline 9 & I nearly always adjust instruction in response to individual student needs. & 4.5000 & Agree \\
\hline 10 & I nearly always use direct instruction when I teach. & 4.3333 & Agree \\
\hline 11 & I do not deviate from my pre planned learning activities. & 4.3333 & Agree \\
\hline \multirow[t]{2}{*}{12} & $\begin{array}{l}\text { I nearly alwaysuse a teaching approach that encourages interaction among } \\
\text { students. }\end{array}$ & 4.6667 & Strongly Agree \\
\hline & Average Mean Score & 4.2917 & Agtee \\
\hline
\end{tabular}


Table 8 shows that the mean score responses (4.2917) from teachers in MSU-TCTO Tampakan High School which means that they "agree" in all of the items for the Instructional Management Scales (IMS) of the Teachers' Classroom Management Practices. It can be deduced in the findings that the teachers usually practiced more on instructional management than behavioral management since they have a greater average mean score in the classroom management as measured by Instructional Management Scale (IMS) than Behavioral Management Scale (BMS).

Table 9 Teachers' Classroom Management Practices as Measured by Behavioral Management Scale (BMS) for MSU-TCTO Tampakan High School

\begin{tabular}{llcc}
\hline No & \multicolumn{1}{c}{ Item/Indicator } & Mean Score & Interpretation \\
\hline $\mathbf{1}$ & $\begin{array}{l}\text { I almost always intervene when student talk at in appropriate times } \\
\text { during class. }\end{array}$ & 5.0000 & Strongly Agree \\
$\mathbf{2}$ & I strongly limit student chatter in the classroom. & 5.0000 & Strongly Agree \\
$\mathbf{3}$ & I reward students for good behavior in the classroom & 4.8333 & Strongly Agree \\
$\mathbf{4}$ & If a student talks to a neighbor, I will move a student away from & 4.5000 & Agree \\
$\mathbf{5}$ & other students. & & Agree \\
$\mathbf{6}$ & I use inputs from students to create classroom rules. & 4.1667 & Disagree \\
$\mathbf{7}$ & I am strict when it comes to student compliance in my classroom. & 4.8333 & Agree \\
$\mathbf{8}$ & I firmly redirect students back to the topic when they get off the & 4.1667 & Agree \\
$\mathbf{9}$ & tasks. & & I insist that students in my classroom follow the rules at all times. \\
$\mathbf{1 0}$ & I closely monitor off-tasks behavior during class. & 4.6667 & Strongly Agree \\
$\mathbf{1 1}$ & I strictly enforce classroom rules to control student behavior. & 4.6667 & Strongly Agree \\
$\mathbf{1 2}$ & If student's behavior is defiant, I will demand that they comply & 4.8333 & Strongly Agree \\
& with my classroom rules. & 4.6667 & Strongly Agree
\end{tabular}

Table 9 shows that the MSU-TCTO Tampakan High School "agree" in almost all of the items in the Behavioral Management Scales (BMS) for the "Teacher's Classroom Management Practices" except that of item 6 (I allow students to get out of their seats without permission.) indicated that they "disagree" as the previous schools did also. Mostly answered by the teachers of this school on the classroom management as measured by Behavioral Management Scale are "Strongly Agree" particularly items 1, 2, 3, 9, 10, 11 , and 12 which indicated that they are more directing and controlling as the previous school did too.

Table 10 Teachers' Classroom Management Practices as Measured by Instructional School Management Scale (IMS) for HadjiOmarsaniTambut National High 


\begin{tabular}{|c|c|c|c|}
\hline No. & Item/Indicator & $\begin{array}{l}\text { Mean } \\
\text { Score }\end{array}$ & Interpretation \\
\hline 1 & I use whole class instruction to ensure a structured classroom. & 3.9286 & Agree \\
\hline 2 & $\begin{array}{l}\text { I nearly always use collaborative learning to explore questions in the } \\
\text { classroom. }\end{array}$ & 4.3571 & Agree \\
\hline 3 & $\begin{array}{l}\text { I engage students in active discussion about issues related to real world } \\
\text { application. }\end{array}$ & 4.5714 & Strongly Agree \\
\hline 4 & I establish a teaching daily routine in my classroom and stick to it. & 4.0714 & Agree \\
\hline 5 & I nearly always use group work in my classroom. & 4.3571 & Agree \\
\hline 6 & I use students input when creating students projects. & 4.2857 & Agree \\
\hline 7 & I nearly always use inquiry-based learning in the classroom. & 4.0000 & Agree \\
\hline 8 & I direct the students' transition fromone learning activity to another. & 4.0714 & Agree \\
\hline 9 & $\begin{array}{l}\text { I nearly always adjust instruction in response to individual student } \\
\text { needs. }\end{array}$ & 4.4286 & Agree \\
\hline 10 & I nearly always use direct instruction when I teach. & 3.7857 & Agree \\
\hline 11 & I do not deviate from my pre planned learning activities. & 3.3571 & Agree \\
\hline \multirow[t]{2}{*}{12} & $\begin{array}{l}\text { I nearly always use a teaching approach that encourages interaction } \\
\text { among students. }\end{array}$ & 4.6429 & Strongly Agree \\
\hline & Average Mean Score & 4.1548 & Agree \\
\hline $\begin{array}{l}L E G \\
3.51\end{array}$ & $\begin{array}{l}\text { ND: } 1.00 \text { - } 1.50 \text { - Strongly Disagree; } 1.51 \text { - } 2.50 \text { - Disagree; } 2.51 \text { - } \\
.50 \text { - Agree; } 4.51-5.00 \text { - Strongly Agree. }\end{array}$ & - Unde & \\
\hline
\end{tabular}

The teachers in HadjiOmarsaniTambut National High School "agree" (Table 10) in all of the items for the Instructional Management Scales (IMS) of the Teachers' Classroom Management Practices as shown in this Table 2.4. Since the responses coming from this school are most likely similar to the responses coming from other secondary schools in Simunul, this indicates that the teachers are emphasizing more on instructional management than behavioral management in their style of managing the classroom which is similar to what the other schools did too.

Table 11Teachers' Classroom Management Practices as Measured by Behavioral

School Management Scale (BMS) for HadjiOmarsaniTambut National High

\begin{tabular}{|c|c|c|c|}
\hline No. & Item/Indicator & $\begin{array}{l}\text { Mean } \\
\text { Score }\end{array}$ & Interpretation \\
\hline 1 & $\begin{array}{l}\text { I almost always intervene when student talk at in appropriate times during } \\
\text { class. }\end{array}$ & 4.3571 & Agree \\
\hline 2 & I strongly limit student chatter in the classroom. & 4.3571 & Agree \\
\hline 3 & I reward students for good behavior in the classroom & 4.2143 & Agree \\
\hline 4 & $\begin{array}{l}\text { If a student talks to a neighbor, I will move a student away from other } \\
\text { students. }\end{array}$ & 4.1429 & Agree \\
\hline 5 & I use inputs from students to create classroom rules. & 4.3571 & Agree \\
\hline 6 & I allow students to get out of their seats without permission. & 1.7143 & Disagree \\
\hline 7 & I am strict when it comes to student compliance in my classroom. & 3.9286 & Agree \\
\hline $\begin{array}{l}8 \\
9\end{array}$ & $\begin{array}{l}\text { I firmly redirect students back to the topic when they get off the tasks. } \\
\text { I insist that students in my classroom follow the rules at all times. }\end{array}$ & $\begin{array}{l}3.9286 \\
4.1429\end{array}$ & $\begin{array}{l}\text { Agree } \\
\text { Agree }\end{array}$ \\
\hline 10 & I closely monitor off-tasks behavior during class. & 4.2857 & Agree \\
\hline 11 & I strictly enforce classroom rules to control student behavior. & 4.6429 & Strongly Agree \\
\hline \multirow[t]{2}{*}{12} & $\begin{array}{l}\text { If student's behavior is defiant, I will demand that they comply with my } \\
\text { classroom rules. }\end{array}$ & 4.3571 & Agree \\
\hline & Average Mean Score & 4.0357 & Agree \\
\hline
\end{tabular}


The HadjiOmarsaniTambut National High School "agree"(Table 11) in almost all of the items in the Behavioral Management Scales (BMS) for the "Teacher's Classroom Management Practices" except that of item 6 (I allow students to get out of their seats without permission.) which indicated that they "disagree" as the previous schools did also as based on their responses given mostly "Agree". We can say, that Tambut National High School teachers observe more instructional management than behavioral management. This is also relevant to the idea of Yavuz (2009) citing Campbell R. J, Evan L; and Neil S. R. (1991) pointed out that teachers who have adopted the role of creating and maintaining learning environment in classroom become more successful compare to the teachers who want to have emphasize power and discipline in the classroom. Therefore, this indicated that the teachers are directing and controlling. Thus, they made a pre-planned effort to prevent misbehavior such as by establishing rules forming a reward and providing opportunity for students input.

Table 12 Teachers' Classroom Management Practices as Measured by Instructional Management Scale (IMS) for Manuk-Mangkaw National High School

\begin{tabular}{|c|c|c|c|}
\hline No. & Item/Indicator & $\begin{array}{l}\text { Mean } \\
\text { Score }\end{array}$ & Interpretation \\
\hline 1 & I use whole class instruction to ensure a structured classroom. & 4.4167 & Agree \\
\hline 2 & $\begin{array}{l}\text { I nearly always use collaborative learning to explore questions in the } \\
\text { classroom. }\end{array}$ & 4.4167 & Agree \\
\hline 3 & $\begin{array}{l}\text { I engage students in active discussion about issues related to real world } \\
\text { application. }\end{array}$ & 4.2500 & Agree \\
\hline 4 & I establish a teaching daily routine in my classroom and stick to it. & 4.2500 & Agree \\
\hline 5 & I nearly always use group work in my classroom. & 4.5000 & Agree \\
\hline 6 & I use students input when creating students projects. & 4.1667 & Agree \\
\hline 7 & I nearly always use inquiry-based learning in the classroom. & 4.3333 & Agree \\
\hline 8 & I direct the students' transition fromone learning activity to another. & 4.5000 & Agree \\
\hline 9 & $\begin{array}{l}\text { I nearly always adjust instruction in response to individual student } \\
\text { needs. }\end{array}$ & 4.5000 & Agree \\
\hline 10 & I nearly always use direct instruction when I teach. & 4.1667 & Agree \\
\hline 11 & I do not deviate from my pre planned learning activities. & 3.5000 & Agree \\
\hline \multirow[t]{2}{*}{12} & $\begin{array}{l}\text { I nearly alwaysuse a teaching approach that encourages interaction } \\
\text { among students. }\end{array}$ & 4.8333 & Strongly Agree \\
\hline & Average Mean Score & 4.3194 & Agree \\
\hline & $\begin{array}{l}\text { VD: } 1.00-1.50 \text { - Strongly Disagtee; } 1.51-2.50 \text { - Disagtee; } 2.51 \\
50 \text { - Agtec; } 4.51-5.00-\text { Strongly Agtee. }\end{array}$ & - Unde & \\
\hline
\end{tabular}

Table 12 shows the responses coming from Manuk-Mangkaw National High School teachers where the responses' mean score is $\mathbf{4 . 3 1 9 4}$ which means they "agree" to all the items in the Instructional Management Scales (IMS) and in fact, in item 12 their responses indicated a "strongly agree", thus encouraging students to interact in the classroom discussion. The responses given are mostly alike to the responses given from the previous schools as mentioned. The mean score result indicates that the teachers observed more instructional management than behavioral management. This is relevant to the idea of Yavuz (2009) citing Campbell R.J, Evan L; and Neil S.R (1991) pointed out that teachers who have adopted the role of creating and maintaining learning environment in classroom become more successful compared to the teachers who want to have power and emphasize discipline in the classroom. 
Table 13 Teachers' Classroom Management Practices as Measured by Behavioral Management Scale (BMS) for Manuk-Mangkaw National High School

\begin{tabular}{|c|c|c|c|}
\hline No. & Item/Indicator & $\begin{array}{l}\text { Mean } \\
\text { Score }\end{array}$ & Interpretation \\
\hline 1 & $\begin{array}{l}\text { I almost always intervene when student talk at in appropriate times } \\
\text { during class. }\end{array}$ & 4.2500 & Agree \\
\hline 2 & I strongly limit student chatter in the classroom. & 4.5000 & Agree \\
\hline 3 & I reward students for good behavior in the classroom & 4.8333 & Strongly Agree \\
\hline 4 & $\begin{array}{l}\text { If a student talks to a neighbor, I will move a student away from other } \\
\text { students. }\end{array}$ & 4.5000 & Agree \\
\hline 5 & I use inputs from students to create classroom rules. & 4.5000 & Agree \\
\hline 6 & I allow students to get out of their seats without permission. & 1.4167 & Strongly Disagree \\
\hline 7 & I am strict when it comes to student compliance in my classroom. & 4.2500 & Agree \\
\hline 8 & I firmly redirect students back to the topic when they get off the tasks. & 4.3333 & Agree \\
\hline 9 & I insist that students in my classroom follow the rules at all times. & 4.5000 & Agree \\
\hline 10 & I closely monitor off-tasks behavior during class. & 4.3333 & Agree \\
\hline 11 & I strictly enforce classroom rules to control student behavior. & 4.4167 & Agree \\
\hline \multirow[t]{2}{*}{12} & $\begin{array}{l}\text { If student's behavior is defiant, I will demand that they comply with my } \\
\text { classroom rules. }\end{array}$ & 4.2500 & Agree \\
\hline & Average Mean Score & 4.1736 & Agree \\
\hline \multicolumn{4}{|c|}{$\begin{array}{l}\text { LEGEND: } 1.00 \text { - } 1.50 \text { - Strongly Disagree; } 1.51 \text { - } 2.50 \text { - Disagree; } 2.51 \text { - } 3.50 \text { - Undecided; } \\
3.51 \text { - } 4.50 \text { - Agree; } 4.51 \text { - 5.00 - Strongly Agree. }\end{array}$} \\
\hline
\end{tabular}

Table 13 shows the Manuk-Mangkaw National High School teachers responses with mean score of 4.1736or "agree" to almost all of the items in the Behavioral Management Scales (BMS) for the "Teacher's Classroom Management Practices" except that of item 6 (I allow students to get out of their seats without permission.) they "strongly disagree" as the previous schools did also. Only item 3 indicated a "Strongly Agree". This indicator showed that the teachers are directing and controlling in their style of managing the classroom. They made a pre-planned effort to prevent misbehavior such as by establishing rules forming a reward and providing opportunities for student input.

Table 14Teachers' Classroom Management Practices as Measured by Instructional Management Scale (IMS) for Ummat National High School

\begin{tabular}{|c|c|c|c|}
\hline No. & Item/Indicator & $\begin{array}{l}\text { Mean } \\
\text { Scorc }\end{array}$ & Intexpretation \\
\hline 1 & I use whole class instruction to ensure a structured classroom. & 4.3846 & Agree \\
\hline 2 & $\begin{array}{l}\text { I nearly always use collaborative learning to explore questions in } \\
\text { the classroom. }\end{array}$ & 4.2308 & Agree \\
\hline 3 & $\begin{array}{l}\text { I cngage students in active discussion about issues related to real } \\
\text { world application. }\end{array}$ & 4.6154 & Strangh Agree \\
\hline 4 & I establish a teaching daily routine in my classtoom and stick to it. & 4.4615 & Agree \\
\hline $\begin{array}{l}5 \\
6\end{array}$ & $\begin{array}{l}\text { I nearly always usc group work in my class room. } \\
\text { I use students input when creating students projects. }\end{array}$ & $\begin{array}{l}4.4615 \\
4.2308\end{array}$ & $\begin{array}{l}\text { Agree } \\
\text { Agree }\end{array}$ \\
\hline 7 & I nearly always use inquiry-based learning in the classroom. & 4.0000 & Agree \\
\hline 8 & $\begin{array}{l}\text { I direct the students' transition fromone learning activity to } \\
\text { another. }\end{array}$ & 4.0769 & Agree \\
\hline 9 & $\begin{array}{l}\text { I ncarly always adjust instruction in response to individual student } \\
\text { needs. }\end{array}$ & 4.4615 & Agree \\
\hline 10 & I nearly always use direct instruction when I teach. & 4.3077 & Agree \\
\hline 11 & I do not deviate from my pre planned learning activities. & 4.1538 & Agree \\
\hline \multirow[t]{2}{*}{12} & $\begin{array}{l}\text { I nearly alwaysuse a teaching approach that encourages interaction } \\
\text { among students. }\end{array}$ & 4.7692 & Sirongly Agree \\
\hline & Average Mean Score & 4.3462 & Agree \\
\hline
\end{tabular}


Table 14 shows the responses coming from Ummat National High School teachers indicated a mean score is $\mathbf{4 . 3 4 6 2}$ which means they "agree" to all the items in the Instructional Management Scales (IMS) and in fact, in items 3 and 12 "strongly agree", thus encouraging students to actively participate and interact in the classroom discussion. The responses showed that UmmatNational High School teachers tend to observe more of Instructional Management than Behavioral Management. The teachers keep on monitoring seatworks of the students, structuring daily routines, use of lectures and students practice versus interactive and other participatory approaches to instruction as their methodologies in order to encourage students to actively interact in the class.

Table 15 Teachers' Classroom Management Practices as Measured by Behavioral Management Scale (BMS) for Ummat National High School

Table 15 Teachers' Classroom Management Practices as Measured by Behavioral Management Scale (BMS) for Ummat National High School

\begin{tabular}{|c|c|c|c|}
\hline No. & Item/Indicator & Mean Score & Interpretation \\
\hline 1 & $\begin{array}{l}\text { I almost always intervene when student talk at in appropriate } \\
\text { times during class. }\end{array}$ & 4.2308 & Agree \\
\hline 2 & I strongly limit student chatter in the classroom. & 4.3077 & Agree \\
\hline 3 & I reward students for good behavior in the classroom & 4.3846 & Agree \\
\hline 4 & $\begin{array}{l}\text { If a student talks to a neighbor, I will move a student away } \\
\text { from other students. }\end{array}$ & 4.2308 & Agree \\
\hline 5 & I use inputs from students to create classroom rules. & 4.3846 & Agree \\
\hline 6 & I allow students to get out of their seats without permission. & 1.6923 & Disagree \\
\hline 7 & $\begin{array}{l}\text { I am strict when it comes to student compliance in my } \\
\text { classroom. }\end{array}$ & 4.1538 & Agree \\
\hline 8 & $\begin{array}{l}\text { I firmly redirect students back to the topic when they get off } \\
\text { the tasks. }\end{array}$ & 4.3077 & Agree \\
\hline 9 & $\begin{array}{l}\text { I insist that students in my classroom follow the rules at all } \\
\text { times. }\end{array}$ & 4.4615 & Agree \\
\hline 10 & I closely monitor off-tasks behavior during class. & 4.4615 & Agree \\
\hline 11 & I strictly enforce classroom rules to control student behavior. & 4.4615 & Agree \\
\hline 12 & $\begin{array}{l}\text { If student's behavior is defiant, I will demand that they comply } \\
\text { with my classroom rules. }\end{array}$ & 4.4615 & Agree \\
\hline & Average Mean Score & 4.1282 & Agree \\
\hline \multicolumn{4}{|c|}{$\begin{array}{l}\text { LEGEND: } 1.00 \text { - } 1.50 \text { - Strongly Disagree; } 1.51 \text { - } 2.50 \text { - Disagree; } 2.51 \text { - } 3.50 \text { - Undecided; } \\
3.51 \text { - } 4.50 \text { - Agtee; } 4.51 \text { - } 5.00 \text { - Strongly Agree. }\end{array}$} \\
\hline
\end{tabular}

Table 15 shows themean score of $\mathbf{4 . 1 7 3 6}$ in the responses coming from Ummat National High School teachers which means they "agree" to almost all of the items in the Behavioral Management Scales (BMS) for the "Teacher's Classroom Management Practices" except that in item 6 (I allow students to get out of their seats without permission.) where they"disagree" on allowing students to get out of their class without permission. Since almost all of the items they answered "Agree" except item 6 showing "Disagree". These indicators mean that they are adopting the same techniques and strategies in managing the classroom situation as what the other secondary schools did too.

Table 16 Teachers' Classroom Management Practices as Measured by Instructional Management Scale (IMS) for Tubig-Indangan National High School 


\begin{tabular}{|c|c|c|c|}
\hline No. & Item/Indicator & $\begin{array}{l}\text { Mean } \\
\text { Score }\end{array}$ & Interpretation \\
\hline 1 & I use whole class instruction to ensure a structured classroom. & 4.4545 & Agree \\
\hline 2 & $\begin{array}{l}\text { I nearly always use collaborative learning to explore questions in the } \\
\text { classroom. }\end{array}$ & 4.7273 & Strongly Agree \\
\hline 3 & $\begin{array}{l}\text { I engage students in active discussion about issues related to real world } \\
\text { application. }\end{array}$ & 4.5455 & Strongly Agree \\
\hline 4 & I establish a teaching daily routine in my classroom and stick to it. & 4.3636 & Agree \\
\hline 5 & I nearly always use group work in my classroom. & 4.4545 & Agree \\
\hline 6 & I use students input when creating students projects. & 4.1818 & Agree \\
\hline 7 & I nearly always use inquiry-based learning in the classroom. & 4.3636 & Agree \\
\hline 8 & I direct the students' transition from one learning activity to another. & 4.1818 & Agree \\
\hline 9 & I nearly always adjust instruction in response to individual student needs. & 4.3636 & Agree \\
\hline 10 & I nearly always use direct instruction when I teach. & 4.3636 & Agree \\
\hline 11 & I do not deviate from my pre planned learning activities. & 4.0909 & Agree \\
\hline \multirow[t]{2}{*}{12} & $\begin{array}{l}\text { I nearly always use a teaching approach that encourages interaction } \\
\text { among students. }\end{array}$ & 4.7273 & Strongly Agree \\
\hline & Average Mean Score & 4.4015 & Agree \\
\hline \multicolumn{4}{|c|}{$\begin{array}{l}\text { LEGEND: } 1.00 \text { - } 1.50 \text { - Strongly Disagree; } 1.51 \text { - } 2.50 \text { - Disagree; } 2.51 \text { - } 3.50 \text { - Undecided; } \\
3.51 \text { - } 4.50 \text { - Agree; } 4.51 \text { - } 5.00 \text { - Strongly Agree. }\end{array}$} \\
\hline
\end{tabular}

The Tubig-Indangan National High School teachers' responses as shown in Table 16 "agree" to all the items in the Instructional Management Scales (IMS) and in fact, in items 2, 3 and 12 they a "strongly agree" thus encouraging students to explore questions and interact in the classroom discussion. The responses of all secondary schools in Simunul are almost all the same in the classroom management practices as measured by Instructional Management Scale. They mostly "Agree". This means that the teachers of Tubig-Indangan National High School did the same way as what the other secondary schools did as mentioned earlier.

Table 17 Teachers' Classroom Management Practices as Measured by Behavioral Management Scale (BMS) for Tubig-Indangan National High School 
Table 17 Teachers' Classroom Management Practices as Measured by Behavioral Management Scale (BMS) for Tubig-Indangan National High School

\begin{tabular}{|c|c|c|c|}
\hline No. & Item/Indicator & $\begin{array}{l}\text { Mean } \\
\text { Score }\end{array}$ & Interpretation \\
\hline 1 & $\begin{array}{l}\text { I almost always intervene when student talk at in appropriate times during } \\
\text { class. }\end{array}$ & 4.3636 & Agree \\
\hline 2 & I strongly limit student chatter in the classroom. & 4.4545 & Agree \\
\hline 3 & I reward students for good behavior in the classroom & 4.5455 & Strongly Agree \\
\hline 4 & $\begin{array}{l}\text { If a student talks to a neighbor, I will move a student away from other } \\
\text { students. }\end{array}$ & 4.0909 & Agree \\
\hline 5 & I use inputs from students to create classroom rules. & 4.1818 & Agree \\
\hline 6 & I allow students to get out of their seats without permission. & 2.3636 & Disagree \\
\hline 7 & I am strict when it comes to student compliance in my classroom. & 4.4545 & Agree \\
\hline 8 & I firmly redirect students back to the topic when they get off the tasks. & 4.2727 & Agree \\
\hline 9 & I insist that students in my classroom follow the rules at all times. & 4.4545 & Agree \\
\hline 10 & I closely monitor off-tasks behavior during class. & 4.2727 & Agree \\
\hline 11 & I strictly enforce classroom rules to control student behavior. & 4.5455 & Strongly Agree \\
\hline \multirow[t]{2}{*}{12} & $\begin{array}{l}\text { If student's behavior is defiant, I will demand that they comply with my } \\
\text { classroom rules. }\end{array}$ & 4.0909 & Agree \\
\hline & Average Mean Score & 4.1742 & Agree \\
\hline
\end{tabular}

Table 17 shows the Tubig-Indangan National High School teachers responses with a mean score of 4.1742or "agree" to almost all of the items in the Behavioral Management Scales (BMS) for the "Teacher's Classroom Management Practices" except that item 6 (I allow students to get out of their seats without permission.) where they "disagree" as the other schools did also. However, items 3 and 11 show a "Strongly Agree". The responses given by this school are also almost similar to the answers of the above mentioned secondary schools. No differences in terms of behavioral management as to practice. In fact this can be noted that Tubig-Indangan National High School and the rest of the secondary schools in Simunul did the same way in terms of methodologies, techniques and strategies in handling the classroom.

Teacher's Classroom management Practices as measured by the Instructional Management Scales (IMS)"'and Behavioral Management Scales (BMS

Table 18 Teachers' Classroom Management Practices asMeasured byInstructional Management Scale (IMS) for all High Schools in Simunul, Tawi-Tawi 


\begin{tabular}{|c|c|c|c|}
\hline No. & Item/Indicator & $\begin{array}{l}\text { Mean } \\
\text { Score }\end{array}$ & Interpretation \\
\hline 1 & I use whole class instruction to ensure a structured classroom. & 4.4064 & Agree \\
\hline 2 & $\begin{array}{l}\text { I nearly always use collaborative learning to explore questions in } \\
\text { the classroom. }\end{array}$ & 4.4665 & Agree \\
\hline 3 & $\begin{array}{l}\text { I engage students in active discussion about issues related to real } \\
\text { world application. }\end{array}$ & 4.5853 & Strongly Agree \\
\hline 4 & I establish a teaching daily routine in my classroom and stick to it. & 4.2433 & Agree \\
\hline 5 & I nearly always use group work in my classroom. & 4.3675 & Agree \\
\hline 6 & I use students input when creating students projects. & 4.2373 & Agree \\
\hline 7 & I nearly always used inquiry-based learning in the classroom. & 4.2830 & Agree \\
\hline 8 & $\begin{array}{l}\text { I direct the students' transition fromone learning activity to } \\
\text { another. }\end{array}$ & 4.1329 & Agree \\
\hline 9 & $\begin{array}{l}\text { I nearly always adjust instruction in response to individual student } \\
\text { needs. }\end{array}$ & 4.5567 & Strongly Agree \\
\hline 10 & I nearly always use direct instruction when I teach. & 4.2780 & Agree \\
\hline 11 & I do not deviate from my pre planned learning activities. & 4.0127 & Agree \\
\hline \multirow[t]{2}{*}{12} & $\begin{array}{l}\text { I nearly alwaysuse a teaching approach that encourages interaction } \\
\text { among students. }\end{array}$ & 4.7633 & Strongly Agree \\
\hline & Average Mean Score & 4.3611 & Agree \\
\hline \multicolumn{4}{|c|}{$\begin{array}{l}\text { LEGEND: } 1.00 \text { - } 1.50 \text { - Strongly Disagree; } 1.51 \text { - } 2.50 \text { - Disagree; } 2.51 \text { - } 3.50 \text { - Undecided; } \\
3.51 \text { - } 4.50 \text { - Agree; } 4.51 \text { - } 5.00 \text { - Strongly Agree. }\end{array}$} \\
\hline
\end{tabular}

Table 18 shows the overall responses of the teacher respondents coming from 8 high schools in the Municipality of Simunul, Tawi-Tawi. It can be noted that the average mean score is $\mathbf{4 . 3 6 1 1}$ which means they "agree" to all the 12 items of the "Teacher's Classroom Management Practices as MeasuredbyInstructional Management Scales (IMS)" in their respective schools. Moreover, it can also be noted that items 3 (I engage students in active discussion about issues related to real world application), 9 (I nearly always adjust instruction in response to individual student needs.) and 12(I nearly always use a teaching approach that encourages interaction among students.) indicated a "strongly agree" ratings and as the most prevailing classroom management practices. On the average, the secondary school teachers under study observe more of instructional management inside the classroom than behavioral management.Instructional management practices that indicated a high mean score on items 3, 9 and 12 show that the teachers aim to monitor students' seat works, structure daily routines, use of lectures and students practice versus interactive and other preparatory approaches to instruction as their methodologies for the purpose of encouraging the students to actively interact in the classroom.

Table 19 below shows the overall responses of the teacher respondents coming from the 8 high schools in the Municipality of Simunul, Tawi-Tawi. The overall or average mean score for responses is $\mathbf{4 . 1 4 3 8}$ or "agree" to all of the items in the Behavioral Management Scales (BMS) for the "Teacher's Classroom Management Practices". It can be noted that items 3 (I reward students for good behavior in the classroom.), and 11 (I strictly enforce classroom rules to control student behavior.) indicated a "strongly agree" ratings and as the most prevailing classroom management practices. The teachers' classroom behavior management practices that got the higher mean particularly on the above mentioned items 3 and 11 indicated that the teachers have primary responsibility for controlling and directing. 
Table 19 Teachers' Classroom Management Practices as Measured by Behavioral Management Scale (BMS) for All High Schools in Simunul, Tawi-Tawi

\begin{tabular}{|c|c|c|c|}
\hline N0. & Item/Indicator & $\begin{array}{l}\text { Mean } \\
\text { Score }\end{array}$ & Interpretation \\
\hline 1 & I almost always intervene when student talk at in appropriate times during class. & 4.1752 & Agree \\
\hline 2 & I strongly limit student chatter in the classroom. & 4.2191 & Agree \\
\hline 3 & I reward students for good behavior in the classroom. & 4.6347 & Strongly Agree \\
\hline 4 & $\begin{array}{l}\text { If a student talks to a neighbor, I will move the student away from other } \\
\text { students. }\end{array}$ & 4.2706 & Agree \\
\hline 5 & I use inputs from students to create classroom rules. & 4.2613 & Agree \\
\hline 6 & I allow students to get out of their seats without permission. & 1.8275 & Disagree \\
\hline 7 & I am strict when it comes to student compliance in my classroom. & 4.2734 & Agree \\
\hline 8 & I firmly redirect students back to the topic when they get off the tasks. & 4.2261 & Agree \\
\hline 9 & I insist that students in my classroom follow the rules at all times. & 4.4574 & Agree \\
\hline 10 & I closely monitor off-tasks behavior during class. & 4.4067 & Agree \\
\hline 11 & I strictly enforce classroom rules to control student behavior. & 4.6625 & Strongly Agree \\
\hline \multirow[t]{2}{*}{12} & $\begin{array}{l}\text { If student's behavior is defiant, I will demand that they comply with my } \\
\text { classroom rules. }\end{array}$ & 4.3116 & Agree \\
\hline & Average Mean Score & 4.1438 & Agree \\
\hline
\end{tabular}

Table 20shows that the variables gender, educational attainment, monthly income, and number of children indicated "negligible correlation". This means that none of the demographic variables showed a significant relationship with the "Teachers' Classroom Management Practices" as measured by Behavioral Management Scales (BMS). Therefore, the hypothesis that states, "There is a significant relationship between the demographic profile and the behavioral management practices of the secondary school teachers," is rejected.

Table 21 Correlation between Demographic Profile and Instructional Management of the Secondary School Teachers

\begin{tabular}{llll}
\hline Variables & $\mathrm{R}$ & $\mathrm{P}-\mathrm{V}$ alue & Interpretation \\
\hline Gender & 0.120 & 0.293 & Negligible Correlation \\
Age & 0.173 & 0.129 & Negligible Correlation \\
Educational Attainment & 0.099 & 0.390 & Negligible Correlation \\
Length of Service & 0.085 & 0.461 & Negligible Correlation \\
Monthly Income & 0.133 & 0.247 & Negligible Correlation \\
Number of Children & 0.085 & 0.462 & Negligible Correlation \\
& & Indication & \\
LEGEND: Coefficient & high correlation & \\
between $\pm \mathbf{0 . 8 0}$ to \pm 1.00 & moderate high correlation & \\
between $\pm \mathbf{0 . 6 0}$ to $\pm \mathbf{0 . 7 9}$ & moderate high correlation & \\
between $\pm \mathbf{0 . 4 0}$ to $\pm \mathbf{0 . 5 9}$ & low correlation & \\
between $\pm \mathbf{0 . 2 0}$ to $\pm \mathbf{0 . 3 9}$ & negligible correlation & \\
between $\pm \mathbf{0 . 0 1}$ to $\pm \mathbf{0 . 1 9}$ & \multicolumn{2}{c}{} \\
\hline
\end{tabular}

All of the variables in the demographic profile were not significant to Instructional Management Scale except the "Monthly Income" which showed low correlation to the "Teachers' Classroom Management Practices" as measured by IMS with correlation coefficient $r=0.354$ which is highly significant $(P=0.001)$. Therefore, the hypothesis 
states, "There is no significant relationship between the demographic profile and the instructional management practices of the secondary school teachers," is rejected, only along monthly income while accepted in all other variables.

Table 22Correlation between Behavioral Management and Instructional Management and Grades of Secondary Students

\begin{tabular}{llll}
\hline $\begin{array}{l}\text { Variables } \\
\text { Behavioral Management Scale } \\
(\mathrm{BMS})\end{array}$ & $\mathrm{R}$ & $\begin{array}{l}\text { P-Value } \\
0.039\end{array}$ & $\begin{array}{l}\text { Interpretation } \\
\text { Negligible Correlation }\end{array}$ \\
$\begin{array}{l}\text { Instructional Management Scale } \\
(\mathrm{IMS})\end{array}$ & 0.14 & 0.901 & Negligible Correlation \\
\hline
\end{tabular}

The “teachers' classroom management practices " as measured by Instructional Management Scale (IMS) and Behavioral Management Scale (BMS) are not significantly related to the academic performance of Grade 10 students where $\mathrm{r}(\mathrm{IMS})=0.14$ and $(\mathrm{BMS})$ $=0.039$ respectively

Table 23 Pearson Correlation Coefficient of the 8 High Schools Teacher's Classroom Management Practices in terms of IMS and BMS, Grades and Demographic Profile of the Teacher-Respondent in the Municipality of Simunul, Tawi-Tawi

\begin{tabular}{|c|c|c|c|c|c|c|c|c|}
\hline \multirow[t]{2}{*}{ Correlation } & \multicolumn{2}{|c|}{ IMS Mean } & \multicolumn{2}{|c|}{ BMS Mean } & \multicolumn{2}{|c|}{ Overall Mean } & \multicolumn{2}{|c|}{ Grades } \\
\hline & r value & $\begin{array}{c}\text { p- } \\
\text { value }\end{array}$ & $\begin{array}{c}\mathrm{r} \\
\text { value }\end{array}$ & $\begin{array}{c}\mathrm{p}- \\
\text { value }\end{array}$ & $\begin{array}{c}\mathrm{r} \\
\text { value }\end{array}$ & $\begin{array}{c}\mathrm{p}- \\
\text { value }\end{array}$ & $\mathrm{r}$ value & $\begin{array}{c}\mathrm{p}- \\
\text { value }\end{array}$ \\
\hline School_id & -.064 & .576 & .134 & .242 & .059 & .609 & $\begin{array}{c}- \\
.512 * *\end{array}$ & .000 \\
\hline Gender & .048 & .673 & .120 & .293 & .109 & .341 & .109 & .341 \\
\hline Age & .049 & .670 & -.173 & .129 & -.094 & .413 & -.093 & .418 \\
\hline HiEdAttain & .069 & .546 & .099 & .390 & .105 & .359 & -.129 & .273 \\
\hline LengthOfService & .181 & .113 & -.085 & .461 & .037 & .745 & .013 & 909 \\
\hline Monthly_Income & $.354 * *$ & .001 & .133 & .247 & $.280 *$ & .013 & .057 & .618 \\
\hline NoOfChildren & .134 & .244 & .085 & .462 & .130 & .258 & -.131 & .254 \\
\hline
\end{tabular}

**.Correlation is significant at the 0.01 level (2-tailed)*. Correlation is significant at the 0.05 level (2-tailed)

By combining the IMS and BMS (MS_mean) as shown in Table 23, only the "Monthly Income" with $\mathrm{r}(\mathrm{MS})=0.280$ and $\mathrm{p}$-value $=0.013$ showed a significant relationship, which means that only the monthly income of the respondents is significantly related to the "Teacher's Classroom Management Practices" as measured by the Instructional and Behavioral Management Scales, while the rest of the demographic profile variables were found to be insignificant.

Table 24 Summary of the One-Way ANOVA for the Teacher's Classroom Management Practices as Measured by Instructional Management Scale (IMS) for All High Schools in the Municipality of Simunul, Tawi-Tawi 
Table 24 Summary of the One-Way ANOVA for the Teacher's Classroom Management Practices as Measured by Instructional Management Scale (IMS) for All High Schools in the Municipality of Simunul, Tawi-Tawi

\begin{tabular}{cccccc}
\hline Source & $\begin{array}{c}\text { Type III } \\
\text { Sum of } \\
\text { Squares }\end{array}$ & df & $\begin{array}{c}\text { Mean } \\
\text { Square }\end{array}$ & F & Significant \\
\hline Corrected Model & $1.082^{\mathrm{a}}$ & 7 & .155 & 1.871 & .084 \\
Intercept & 1825.812 & 1 & 1825.812 & 22097.883 & .000 \\
School_id & 1.082 & 7 & .155 & 1.871 & .084 \\
Error & 7.271 & 88 & .083 & & \\
Total & 1834.165 & 96 & & & \\
Corrected Total & 8.353 & 95 & & &
\end{tabular}

a. R Squared $=.130$ (Adjusted R Squared $=.060)$

Table 24 shows a one-way ANOVA summary and it found out that since the value of Sig (0.084) indicates higher than the pre-set level of significance value of 0.05 , there is no significant difference between schools regarding the mean score responses, and that these responses are in complete agreement for the 12 items of the "Instructional Management Scale (IMS)" to measure the "Teacher's Classroom Management Practices" for the high school teachers in the Municipality of Simunul, Tawi-Tawi. Therefore, post hoc analysis wasn't needed since there is no significant difference when compared. Thus, the null hypothesis that states, "There is no significant difference in the Classroom Management practices in terms of Instructional Management practices of the secondary school teachers by school," is accepted.

Table 25Summary of the One-Way ANOVA for the Teacher'sClassroom Management Practices as Measured by Behavioral Management Scale (BMS) for All High Schools in the Municipality of Simunul

Table 25Summary of the One-Way ANOVA for the Teacher'sClassroom Management

Practices as Measured by Behavioral Management Scale (BMS) for All High Schools in the Municipality of Simunul

\begin{tabular}{lccrrr}
\hline Source & $\begin{array}{l}\text { Type III Sum } \\
\text { of Squares }\end{array}$ & df & Mean Square & F & Significant \\
\hline Corrected Model & $2.457^{a}$ & 7 & .351 & .533 & .807 \\
Intercept & 1648.448 & 1 & 1648.448 & 2504.760 & .000 \\
School Id & 2.457 & 7 & .351 & .533 & .807 \\
Error & 57.915 & 88 & .658 & & \\
Total & 1708.821 & 96 & & & \\
Corrected Total & 60.372 & 95 & & &
\end{tabular}

a. R Squared $=.041$ (Adjusted $R$ Squared $=-.036)$

Table 25 shows a one-way ANOVA summary and it found out that since the value of Sig (0.807) indicates higher than the pre-set level of significance value of 0.05 , there is no significant difference between schools regarding the mean score responses, and that these responses are in complete agreement for the 12 items of the "Behavioral Management Scale (BMS)" to measure the "Teacher's Classroom Management Practices" for the High School teachers in the Municipality of Simunul, Tawi-Tawi. 
Therefore, the null hypothesis that states, "There is no significant difference in the classroom management practices in terms of Behavioral Management of the secondary school teachers by school," is accepted.

\section{Conclusion and Recommendation}

This study on classroom management practices implies that teachers should maintain or further improve their classroom management practices in terms of behavioral and instructional management to improve academic performance of students performance of the students depends on their attitude, maturation for success and the study habit. Classroom management and practices are very significant in the improvement of student's learning. Effective classroom management would produce quality graduates who are globally competitive. However, it is clear that economic status of the teachers significantly influenced their classroom management practices as measured by the Instructional Management Scale. Thus, teaching and learning process are dependent on each other. As such, the following are the recommended: a) The principals should organize teachers to invest in cooperatives for additional income provided it doesn't interfere with the classroom activities; b) The government should provide incentives like salary increment to motivate and inspire them to do their job; c) Teachers must have access to seminars and workshops to enhance their competence and for professional growth; d) Classroom visitations by the principals must be done regularly to see to it that teachers implement the classroom management strategies and techniques that they acquired from trainings or workshops; e) Researches in classroom management must be pursued by school principals so that findings obtained from their studies will serve as baseline data for their training programs for the teachers; and f) Future researchers on classroom management practices should add some variables for more meaningful findings of the study.

\section{References}

[1] Aiken, A.M. (2002). Parental Involvement. The Key to Academic Success.

Dissertations Abstract International 63 (6) 2005;

[2] Blooms and Martines (2009). Management Goals and Strategies: Prevent Students from Developing Problems. (Fifth edition) New York, McGraw Hill, 2012;

[3] Bradley, D.F., Pauley, J.A., and Parley, J.F. (2005). Effective Classroom Management: Six keys to Success Roman and Littlefield Education;

[4] Browers, A; and Tomic, W. (2000). A Longitudal Study of Teacher Burnout and Perceived Self Efficacy in Classroom Management Teaching and Teacher Education, 16, 239-253;

[5] Borwn, D.F. (2005). Significance of Congruent Communication in Effective Classroom Management. Clearing Home. A Journal of Educational Strategies, Issues and Ideas, pp 1-12;

[6] Buddahim, HjaMechu U. (2012). Classroom Management Practices of Public Secondary Teachers of Bongao, Unpublished Master's Thesis, MSU-Tawi-Tawi College of Technology and Oceanography, Bongao, Tawi-Tawi;

[7] Depry, R.L; and Sugai, G. (2002). The Effect of Active Supervision and Precorrectional Strategy for Managing Predictable Behavior Problems. Intervention in School and Clinic, 28, 143-15-

[8] Di Martini - Scully, D., Bray, M.A., and Kehli, T.J. (2000). A Packaged Invention to Reduce Disruptive Behaviors in General Education Students. Psychology in Schools, 37 -149 - 156; 
[9] Evertson, C. M., and Emmer, E.T. (2006). Improving Classroom Management: An experiment in Elementary Classrooms. The Elementary School Journal, 84, 172-188; Evertson, C.M., and Weinstein, C. (2006). Classroom Management as Field of Inquiry In C.M., and Weinstein (Eds.), Handbook of Classroom Management: Research Practice, and Contemporary Issues (pp. 3-5). Mahwah, N.J: Lawrence Erlbaun Associates, Inc; [10] Garett, T. (2006). Student and Teacher Centered Classroom Management. A Case Study of Three Teacher's Beliefs and Practices Papers Presented at the Annual Meeting of the American Educational Research Association (AERA);

[11] Greer-Chase, M. Rhodas, W. A., and Kellam, S. G. ( 2002). Why the prevention of aggressive disruptive behaviors in middle school must begin in elementary school. The clearing house 75(5)-242-245;

[12] Ingersoll, R.M., and Smith, T.M. (2003).The Wrong Solution to the Teacher Shortage: Educational Leadership, 60, 30-33;

[13] Jovelete, K. and Nelson, C. (2010). Adopting Positive Behavioral Interventions and Supports for Secure Juvenile Justice Settings, Improving Facility - Wide Behavior, Behavioral Disorders, 36 (1), 28-42;

[14] Kauffan, J. M. (2005). Characteristics of Emotional and Behavioral Disorders of Children and Youth ( $8^{\text {th }}$ edition). Upper Saddle River, New Jersey: Pearson Education, Inc.

[15] Martin, N.K. and Saas, D.A. (2010). Constructive Validation of the Behavior and Instructional Management Scale; In Teacher and Teacher Educational Journal 300, pp. 127 home page: $\underline{w w w . e l s e v i e r / l o c a t e d ~ T A T E ; ~}$

[16] Rose, L.C. and Gallup, A.M. (2005). The $37^{\text {th }}$ Annual Phi Delta Kappa / Gallup Poll of the Public's Attitude Towards the Public Schools. Phil Delta Kappa, 87 (1), 41-57;

[17] Sayeski, K. and Brown, M. (2011). Developing A Classroom Management Plan Using A Tired Approach - Teaching Exceptional Children, 44 (1), 8-17;

[18] Schmidth, M. (2006). It's Just A False Sense of Reality, Student Teachers' Latten at Annual Meeting of the American Educational Research Association, San Francisco, April, 2006;

[19] Shawer, S.F. (2006). Effective Teaching and Learning in Generic Education and Foreign Teaching Language Teaching Methodology Learner's Cognitive Style, Foreign Language Skills, Instruction and Teacher's Professional Development Cairo: Dar El-F; [20] Shawer, S.F. (2010). Classroom Level Curriculum Development; EFL Teacher as Curriculum Designers, Curriculum Makers and Curriculum Transmitters, Teaching and Teacher Education, pp.2,26 and 173-184;

[21] Smith, D.L. and Smith, B.J. (2006). Perspective of Violence: The Views of Teachers Who Left Urban Schools. The High School Journal, 89, 34-42;

[22] Victor, K.R. (2005). Identifying Effective Behavior Management in the Early Childhood Classroom, Unpublished M.A. Thesis, Cedarville (Cited in Shawer, 2010); [23] Woolfolk, A.E. Hoy, W.K. and Weinstein, C.S. (2006). Student and Teacher Perspective in Classroom Management, In Carol M. Evertson and Card S. Weinstein's (Eds.) Handbook of Classroom Management;

[24] Yousef, Germine (2012). An Investigation Into The Influence of Teachers Classroom Management Beliefs and Practiceson Classroom Procedures, University of Melbourne, Australia;

[25] Zinimerman, Jennifer (2006). Classroom Behavior Management Strategies. 